\title{
THE ASUNCIÓN RIFT, EASTERN PARAGUAY: A PRELIMINARY INTERPRETATION.
}

\author{
H.H.G.J.Ulbrich ${ }^{1}$ \\ J.B.Presser ${ }^{2}$
}

The Asunción rift, eastern Paraguay, is a remarkable structure, first noticed by Degraff. It is a segmented, "lazy Z", left-stepping rift system, starting at Asunción, to the west, with a NW-SE direction. It then turns next into a E-W trending middle section, finally resuming, to the east, its initial NW-SE course. Its endings, at both extremes, are ill-defined. Total E-W length is about $150 \mathrm{Km}$, and width varies between 20 and $40 \mathrm{~km}$. The E-W section represents the connecting, sheared neck of the stepped rift system, brought about by dextral movement of a pair of shear components with an E-W direction.

Subsidence within the central segment reached over 600 meters (field work by J.B.Presser) and is not well established in the other sections.

Alkaline occurrences (the "Central alkaline province", eastern Paraguay) are found within the rift system. Many of the rocks crystallized from mantle-derived magmas. The western occurrences, in the Asunción segment, are seen mainly as isolated plugs and small bodies, with a sodic chemical tendency. Ages seem to vary, from the Paleocene to the Oligocene (data by Bitschene). In the central sheared segment, alkaline rocks show $\mathrm{K}$ enrichment, and are emplaced as dike swarms and smaller plugs and chimneys; some lava fields and breccias are also found. In the central part of this segment, dikes show a general N30-50W strike, slightly curving over, to the north, into a northerly direction. Ages of these occurrences are around $130 \mathrm{Ma}$ (Bitschene and others, confirmed by C.B. Gomes, V. Velazquez and coworkers), thus belonging to the $130 \mathrm{Ma}$ "peak" of alkaline magmatism in these regions (Ulbrich et al., 1991; Bol. IG-USP, Publ.Esp, 9:87-92).

\footnotetext{
${ }^{1}$ Departamento de Mineralogia e Petrologia, Instituto de Geociências, USP.

2Pós-Graduação, Instituto de Geociências, USP.
} 
Field work on the structure is still in its infancy; some local progress was made by the mapping of the La Colmena sheet (J.B. Presser). Nevertheless, the observed geometry is clearly compatible with some models available in the literature, and can be analyzed in this context.

The dikes in the E-W segment are emplaced within extensional fractures (EF), some of which opened repeatedly, clearly formed by a dextral set of shear components. EF in rigid rocks should lie at about $45^{\circ}$ of the shear directions, but are not expected to be curved. This pattern can be explained by: 1) local structural anisotropies in the basement; 2) compressional components during shearing (angle between EF and border shear increasing with increasing compression, cf. DRESER 1991; Tectonophys., 188:239-247), suggesting that EF to the north formed earlier than EF in the central part, in quick sequence, with compression diminishing at the same time; 3) change in the sense of shearing, from dextral to late sinistral.

The fracturing started at about $130 \mathrm{Ma}$ (minimum age), more or less contemporaneously with the appearance of Paraná Basin diabase dikes in the region (general N45W strike). EF, once formed, must also grow downwards, reaching mantle sources and generating primitive liquids under a pressure relief situation. EF are thus not only pathways and emplacement sites, but are also the local control for mantle magma generation (possibly also within the lower crust).

The system was inactive (?) for a time, resuming magma generation in the Tertiary, but now only in the Asunción limb; younger rocks in the central segment are apparently absent.

These aspects connect rift and magma generation with the opening of the South Atlantic Ocean (132 Ma ago), which propagated itself northwards in a $20 \mathrm{Ma}$-interval (to $110 \mathrm{Ma}$ ). The initial opening created a block displacement in a clockwise direction, which may be responsible for the equally clockwise, dextral, displacement in the E-W rift segment.

In the Tertiary, this segment apparently remained closed, so that an inversion in the shear direction must have happened, opening up new eruption ways in the Asunción segment. Changes between dextral and sinistral shearing are probably the result of the interplay between rates of opening in the Middle Atlantic Ocean and subduction at the border of the South American plate (cf. Riccomini, 1989; Tese de Doutoramento, 256p.).

(Discussions with C. Riccomini are gratefully acknowledged) 